INSIGHTS INTO REGIONAL DEVELOPMENT

ISSN 2669-0195 (online) http://jssidoi.org/IRD/

2021 Volume 3 Number 1 (March)

http://doi.org/10.9770/IRD.2021.3.1(7)

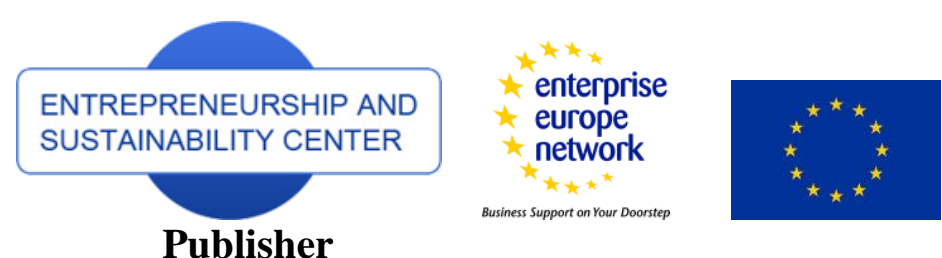

http://jssidoi.org/esc/home

\title{
COMPETENCE DEVELOPMENT FOR INDUSTRY 4.0: QUALIFICATION REQUIREMENTS AND SOLUTIONS
}

\author{
Anna Shevyakova ${ }^{1,2}$, Eleonora Munsh ${ }^{3}$, Malika Arystan ${ }^{4}$, Yelena Petrenko ${ }^{5}$ \\ ${ }^{1}$ LLP "Rational solutions" Microdistrict Orbita-1 11/1, Karaganda 100 000, Republic of Kazakhstan \\ ${ }^{2}$ PI "Academy Bolashaq", st. Erubaeva, 16, Karaganda, Republic of Kazakhsta, 100000 \\ ${ }^{3}$ EPAM Kazakhstan, Ermekova str., 58/3, Karaganda, Republic of Kazakhstan, 100000 \\ ${ }^{4}$ Karaganda Economic University, Akademicheskaya str. 9, Karaganda, Republic of Kazakhstan, 100000 \\ ${ }^{5}$ Plekhanov Russian University of Economic, Stremyanny lane 36, Moscow, Russia, 117997 \\ E-mails: ${ }^{1,2} \frac{\text { shevyakova.anna@gmail.com }}{{ }^{5} \text { petrenko_yelena@bk.ru }}$ eleon $;{ }^{4}$ malika_arystan@mail.ru;
}

Received 15 August 2020; accepted 20 December 2020; published 30 March 2021

\begin{abstract}
The article reveals the requirements for the entry of the world economy into the fourth industrial revolution and Industry 4.0 to the competence of personnel. Industry 4.0 promises new digital solutions to optimize the entire flow of value creation in production systems. Existing production systems are often based on a philosophy of continuous improvement and lean management. The increasing digitalisation of production processes is placing new demands on employee competence. The article discusses and analyzes the necessary competences for successful integration of Kazakhstan and Russian enterprises into Industry 4.0. The article provides systematization of company specific competences and skills of employees, as well as the author's roadmap of implementation for competence development in Industry 4.0 and on its basis recommendations and solutions for enterprises are formed.
\end{abstract}

Keywords: Industry 4.0.; Competence; Roadmap; Fourth Industrial Revolution; Digitalization; Companies

Reference to this paper should be made as follows: Shevyakova, A. Munsh, E., Arystan, M., Petrenko, Y. (2021). Competence development for Industry 4.0: Qualification requirements and solutions: Insights into Regional Development, 3(1), 124-135. http://doi.org/10.9770/IRD.2021.3.1(7)

JEL Classifications: D21, I26, J24, O30

\section{Introduction}

A successful transition to Industry 4.0 in the coming years will determine the competitiveness and future viability of Russian and Kazakh industry, as well as the creation of added value in Russia and Kazakhstan as a new place to locate business. Technological opportunities for linking facilities, data and processes offer both opportunities to

\footnotetext{
* This research was supported by the project, which has received funding from Committee of Science of the Ministry of Education and Science of the Republic of Kazakhstan within the framework of scientific grant AP05134987 "Innovative receptivity of national economies of the EAEC countries: system characteristics, evaluation, management mechanisms".
} 


\section{INSIGHTS INTO REGIONAL DEVELOPMENT}

ISSN 2669-0195 (online) http://jssidoi.org/jesi/

2021 Volume 3 Number 1 (March)

http://doi.org/10.9770/IRD.2021.3.1(7)

Make your research more visible, join the Twitter account of INSIGHTS INTO REGIONAL DEVELOPMENT:

@IntoInsights

improve the efficiency of industrial processes and constructive potential for developing new business models. This will revolutionise not only products and production, but also industrial value creation. It is expected that Industry 4.0 will benefit both large companies and small and medium-sized enterprises (SMEs). At the same time, Industry 4.0 is transforming the world of work in a sustainable way. Increasing networking, flexibility and complexity of processes are placing new demands on the skills of companies and their employees. In addition, Industry 4.0 is also changing the structures and forms of organization within companies and the design of workplaces. However, digital change does not follow a deterministic pattern, but can and should be shaped. There are many different development scenarios that depend on the interaction between technology, people and the organization and are determined by decisions at the level of operational, corporate strategy and work policies, as well as the prevailing framework conditions.

Germany launched the national programs of the "organized" digital economy by adopting the "Industry 4.0" concept in 2012. To date, such strategies have been adopted and provided with regulatory documents in almost two dozen countries from the local "Smart Nation" in Singapore (2015) to the global Chinese concept "Internet +" (2015) and the launch of the Russian digital economy program (2016). The European Union introduces a wide array of financial instruments for supporting of innovative activity of enterprises in years 2021-2027 (Wyrwa, 2020). Issues of economic development, which take into account regional peculiarities, peculiarities of formation of economic and political associations related to development of 4.0, have been repeatedly considered in the works of economists and sociologists (Boronenko, Lavrinenko, 2015; Shevyakova, Petrenko, 2019; Ślusarczyk et al., 2020; Tvaronaviciene, Burinskas, 2020).

The main problem of research in the field of digitalization is that it fixes an already established situation and is looking for adaptation to digital technologies. Researchers, providers of training and professional development in the field of E-competencies and digital skills do not take into account that a generation is coming to jobs that already perceive digital reality as part of everyday life. Also, during training, the growing pool of requirements for E-competencies is not always integrated as new content into training materials. The technical and especially the socio-technical aspects, which are the central component of digital processing in the learning process, are often not considered. The focus continues to be on the instrumental level and themes.

A key challenge in skills development for Industry 4.0 is to avoid and/or close the dual digital divide: between large companies and small and medium-sized enterprises on the one hand, and between highly and low-skilled workers on the other. Important levers in this regard are the framework conditions for primary and continuing education and training in schools, colleges and universities, as well as in companies.

The main issue of this study is the justification of the "gap" between the existing digital reality, the requirements of employers arising under the influence of Industry 4.0 and the possibility of a response or specific changes for educational institutions to form the necessary competencies.

The purpose of the study is to systematize company specific competencies and skills of employees based on the analysis of necessary competencies for successful integration of Kazakhstan and Russian enterprises into Industry 4.0, to develop an author's implementation roadmap for competence development in Industry 4.0, and to generate recommendations and solutions for enterprises.

Also, the objectives of the study are to predict possible changes under the influence of Industry 4.0 in activities: - corporate management at enterprises, if necessary, with the creation of their own Industry 4.0 Competence Centers; 
INSIGHTS INTO REGIONAL DEVELOPMENT

ISSN 2669-0195 (online) http://jssidoi.org/jesi/

2021 Volume 3 Number 1 (March)

http://doi.org/10.9770/IRD.2021.3.1(7)

Make your research more visible, join the Twitter account of INSIGHTS INTO REGIONAL DEVELOPMENT:

@IntoInsights

- Universities, as well as public and private educational institutions;

- government agencies;

- Associations, chambers and unions, including public and professional.

Most of the world's companies see Industry 4.0 as an opportunity. At the same time, there are still many questions concerning its implementation. Small and medium-sized enterprises, in particular, are much more cautious about the possibilities of the fourth industrial revolution than large companies and, compared to them, have a greater need to develop - both to implement Industry 4.0 and to improve the skills of their employees (Dzwigol et al. 2020). Central to the development of competencies for companies of all sizes are the topics of data evaluation and analysis, cross-industry know-how and process management, interdisciplinary thinking and action, as well as customer relationship management and leadership competence. Equally important for companies is the strengthening of IT competencies in terms of comprehensive and interdisciplinary skills on a large scale. Nevertheless, large companies and small and medium-sized enterprises also have different priorities when it comes to qualifications for Industry 4.0. For example, large companies pay more attention to data-centric technologies and skills, such as artificial intelligence. SMEs, on the other hand, pay special attention to clientoriented processes and skills, as well as skills related to infrastructure and organization, such as social and communication skills. Successful qualification for Industry 4.0 cannot be obtained solely through "traditional" learning and development formats, such as full-time education in the classical undergraduate and graduate systems.

\section{Skills Development for the Industry 4.0}

Industry 4.0 describes an economic paradigm shift that brings both opportunities to improve process efficiency and the potential for the development and transformation of value addition and new business models of (industrial) companies. Digital change is increasingly breaking down tight value chains. Flexible value-added networks, platform markets and innovative intellectual services are replacing them. The real-time networking of products, processes and infrastructures heralds a fourth industrial revolution in which supply, production, service and delivery, as well as customer service, are linked to each other over the Internet. Both the increase in process efficiency in line with Industry 4.0 and the development and implementation of new business models during digitization require new or changed management and workforce skills.

The fourth industrial revolution is also leading to sustainable changes in the world of work. The new degree of flexibility and digital networks require innovative qualification solutions that are available depending on the situation and make the behavior of autonomous cyber-physical systems transparent to humans. Currently, there is still a lack of systematic surveys on the competence requirements of Russian and Kazakh companies. In particular, little is known yet about the needs of small and medium enterprises. In addition, there is a lack of suitable qualification proposals that would prepare both experienced employees and newcomers to the profession specifically for Industry 4.0.

The sector of competence development research for Industry 4.0 is based on the fundamental assumption that: - there is a significant need for competence development for Industry 4.0 at Russian and Kazakh enterprises,

- small and medium enterprises set different priorities in the development of competencies compared to large enterprises,

- Targeted staff development measures are needed as a key to generating digital change. 
INSIGHTS INTO REGIONAL DEVELOPMENT

ISSN 2669-0195 (online) http://jssidoi.org/jesi/

2021 Volume 3 Number 1 (March)

http://doi.org/10.9770/IRD.2021.3.1(7)

Make your research more visible, join the Twitter account of INSIGHTS INTO REGIONAL DEVELOPMENT:

@ IntoInsights

The fourth industrial revolution is not only a long-term change in the existing value-added and industrial production models, but also in the world of work, the forms of organisation in enterprises and the competence and qualification requirements of the workforce. However, the prospects for the future development of work, the competence profiles of employees and the impact on employment are assessed differently by different researchers (Abele et al., 2015, 2017; Monostori et al., 2016; Kagermann et al., 2013; Liker, 2004; Bauernhansl et al., 2016). The debate on competence and qualification development requirements for Industry 4.0 is currently in its infancy. A clear forecast of the expected development as well as a clear definition of competencies is proving to be difficult. For example, estimates of possible future scenarios for the development of job requirements and the resulting qualification requirements vary considerably, but all researchers agree that skills and competence development will play a central role in the implementation of Industry 4.0 and that the requirements for employees will increase (Metternich et al., 2017; Tisch et al.2013; Enke et al.2015; Meudt et al. 2017). This article cannot provide a comprehensive analysis, but it does attempt to contribute independently to the overall picture and identify the skills needs for Industry 4.0 based on empirical evidence. Based on this, recommendations for action for companies, policies and education providers will be made, and methodological entry points for qualification solutions will be identified. The starting point is that the digital change and implementation of Industry 4.0 does not follow a deterministic model, but rather that there are various technical and organizational alternatives that can be influenced and shaped by specific company and labour policy decisions. As a social and technical system, Industry 4.0 focuses on the interdependent linkages between all elements of the production system. It takes into account the interactions between technology, people and organization, as well as the operating and policy environment, strategic and regulatory specifications, networking and value chain development (see Figure 1).

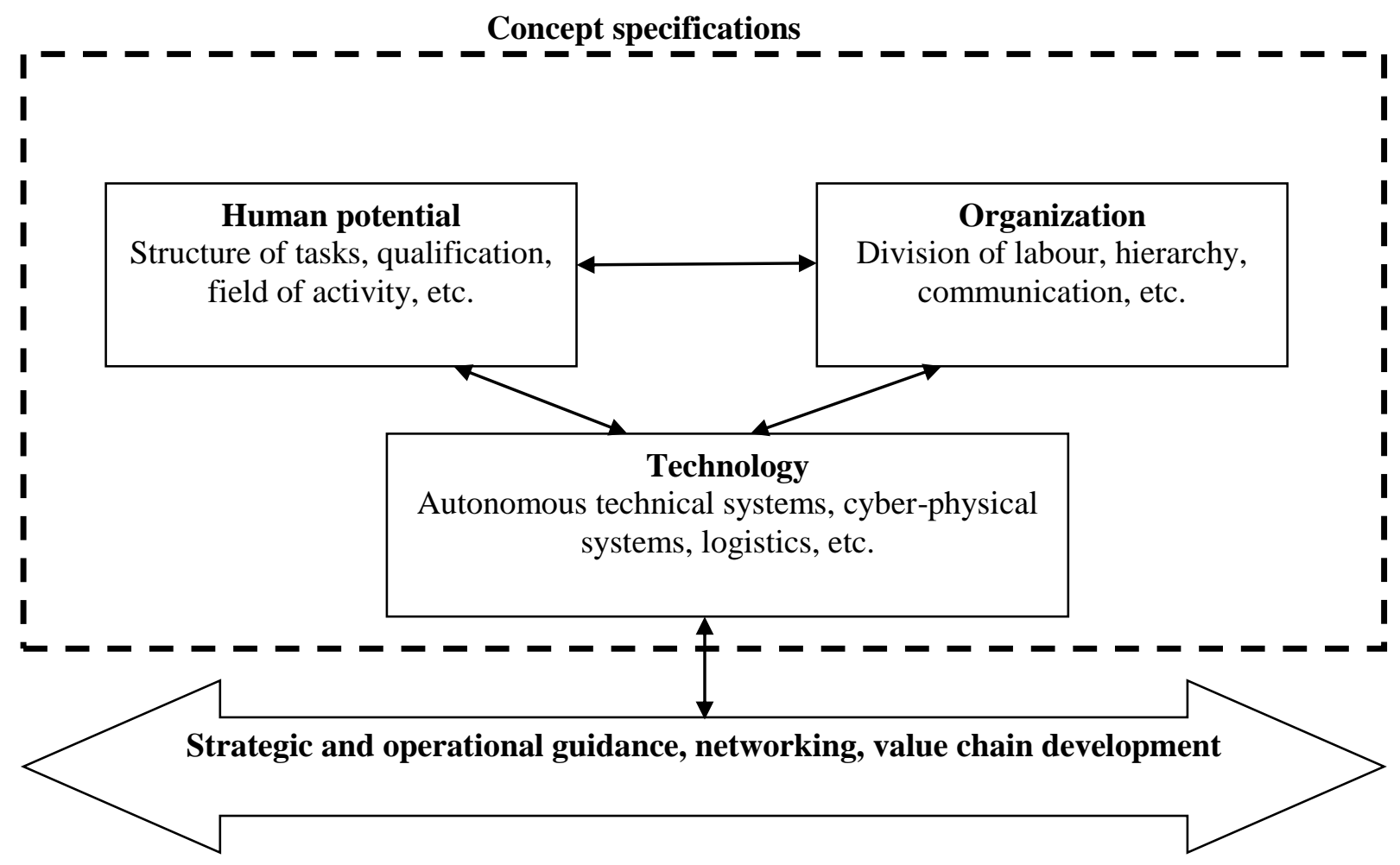

Fig. 1. Industry 4.0 as a socio-economic system Source: composed by the authors 
INSIGHTS INTO REGIONAL DEVELOPMENT

ISSN 2669-0195 (online) http://jssidoi.org/jesi/

2021 Volume 3 Number 1 (March)

http://doi.org/10.9770/IRD.2021.3.1(7)

Make your research more visible, join the Twitter account of INSIGHTS INTO REGIONAL DEVELOPMENT:

@ IntoInsights

The implementation of Industry 4.0 opens up a wide range of development options. While technology-oriented approaches emphasize the far-reaching replacement of human forms of operation by technical equipment and systems, complementary approaches focus on the complementary distribution of tasks and the interaction between man and machine. Since it can be assumed that the diffusion of digital technologies will not occur simultaneously and that there will be significant challenges at the human, operational and organizational levels, complementary design concepts in particular have great technological and economic potential for the implementation of Industry 4.0 .

\section{Future qualification needs and use of professional development tools}

A decisive component for the successful implementation of Industry 4.0 in enterprises and the expansion of opportunities for the future working world is the qualification of employees. This requires, on the one hand, the determination of future requirements for company competences (company specific competences). A company can meet these needs through technology acquisition, external consulting, recruitment, cooperation with external service providers or training of its own staff. On the other hand, expected skills, which are important for the company's own employees as well as their skills, should be specified.

A change in job descriptions places new demands on the skills needed in companies and on the skills of the workforce. The results of the research made it possible to systematize company specific competences and skills of employees (see Table 1):

1) Technology and data-centric competencies and skills, which cover special competences in development, application and mastery of digital technologies.

2) Process and customer-centric Competences and Skills describe the understanding of relationships in valueadded networks, including the organization and coordination of customer relationships.

3) Infrastructure and organization oriented competencies and skills relate to the work with the main technical components in the enterprise and soft skills.

Table 1. Systematization of company specific competences and skills of employees

\begin{tabular}{|c|c|c|}
\hline Initiatives focused on & Competencies specific to the company & Employee's Skills \\
\hline Technology / Databases & Data evaluation and analysis \\
& $\begin{array}{c}\text { Information Technology Security } \\
\text { Cloud architectures } \\
\text { Artificial Intelligence } \\
\text { User support/service technology }\end{array}$ & $\begin{array}{c}\text { Interdisciplinary thinking and action } \\
\text { Mastery of complex content } \\
\text { Ability to interact with machines } \\
\text { Competence in problem solving and } \\
\text { optimization }\end{array}$ \\
\hline Processes / customers & Process Management \\
& Customer relationship management & IT business analysis \\
& E-commerce/E-marketing & Expanding process know-how \\
& Consulting & $\begin{array}{c}\text { Participation in innovation processes } \\
\text { Thility to coordinate work processes } \\
\text { Service orientation }\end{array}$ \\
& & $\begin{array}{c}\text { Interdisciplinary thinking and action } \\
\text { Mastery of complex content } \\
\text { Ability to interact with machines } \\
\text { Competence in problem solving and } \\
\text { optimization }\end{array}$ \\
\hline Infrastructure / organization & Leadership competence \\
& Independent solutions \\
& Processing specific IT systems & Social/communication competence \\
\hline
\end{tabular}

Source: composed by the authors 


\section{INSIGHTS INTO REGIONAL DEVELOPMENT}

ISSN 2669-0195 (online) http://jssidoi.org/jesi/

2021 Volume 3 Number 1 (March)

http://doi.org/10.9770/IRD.2021.3.1(7)

Make your research more visible, join the Twitter account of INSIGHTS INTO REGIONAL DEVELOPMENT:

@ IntoInsights

The described competencies and skills focus primarily on the opportunities offered by Industry 4.0 to improve process and production efficiency. However, in connection with the development and implementation of innovative business models, new and broad competencies are also needed. This is indicated, for example, by competences in data evaluation and analysis, skills in interdisciplinary thinking or participation in innovative processes, but also include, for example, client experience.

Companies' priorities for targeted development of company specific competences in the future also reflect the identified needs. According to previous studies, less than $25 \%$ of companies have special training and professional development programs for Industry 4.0, and naturally large companies are significantly ahead of SMEs. However, interviews with experts from academia and industry suggest that individual modules and building blocks of existing training and development programmes indirectly address selected issues for Industry 4.0 .

\section{Recommendations for action}

The study confirms that there is a significant need for intensive progress in Russian and Kazakh companies with the development of competencies for Industry 4.0. In addition, there is a need to take into account the specific needs and priorities of small and medium-sized companies. It is also important that the targeted qualification of employees becomes the key to shaping digital change.

A decisive goal for the development of competencies for Industry 4.0 at Russian and Kazakh enterprises and the corresponding qualifications of existing employees is to avoid the so-called "digital divide", as digitalization is the fundamental basis for Industry 4.0. However, the successful application of such modern digital technologies cannot be achieved by delegating such topics only to IT specialists, but requires a comprehensive understanding of methods and concepts by users. However, this knowledge and experience is subject to complex and, depending on the target group, previously unknown relationships.

Due to the importance of digitalization, it is important to counteract the possible gap between the large companies that are pioneers in the implementation of Industry 4.0 and the numerous small and medium-sized enterprises that are still in a catch-up position with Industry 4.0. In order to support small and medium sized enterprises in the implementation of the Industry 4.0 standard and in the professional development of their employees, it is necessary first of all to familiarize companies with the potential and problems of Industry 4.0. This applies to both management and staff.

In order to facilitate the development of competencies for Industry 4.0, the following recommendations should be taken into account by the companies:

Developing framework conditions and raising awareness

Although most companies see Industry 4.0 as a breakthrough opportunity, small and medium enterprises have mixed views on this topic. In order to reduce the number of reservations, it is necessary to create an understanding of the causes and a revolutionary idea of Industry 4.0. Dedicated decentralized process management is not an end in itself, but preserves a company's ability to act and respond in future complex and rapidly changing market conditions. 


\section{INSIGHTS INTO REGIONAL DEVELOPMENT}

ISSN 2669-0195 (online) http://jssidoi.org/jesi/

2021 Volume 3 Number 1 (March)

http://doi.org/10.9770/IRD.2021.3.1(7)

Make your research more visible, join the Twitter account of INSIGHTS INTO REGIONAL DEVELOPMENT:

@IntoInsights

For companies that are pioneers in Industry 4.0, it may be appropriate to promote themselves as pioneers to achieve competitive and image advantage. For example, implementing software to digitize office and administrative processes can lead to rapid success: increased productivity and data security, better compliance with standards and improved customer satisfaction. Companies should consider the costs incurred in this regard as an investment and evaluate them from a forward-looking perspective.

Further develop business models

A critical analysis of the current business model follows directly from an understanding of the destructive nature of Industry 4.0 for established and traditional ways of doing business. This can be changed due to the introduction of new technologies, for example, digitalization facilitates contact with end users and, if necessary, direct sale of products. One-component production technologies - such as 3D printing - will change the supply landscape and raise customer expectations for greater individuality. If the business model and, thus, technological process at the enterprise changes, it is necessary to be convinced that suppliers and other partners also master new requirements.

\section{Targeted change management}

The digitalization and implementation of Industry 4.0 is usually accompanied by changes in organizational structure (e.g. by reducing the hierarchy in favour of greater personal responsibility) and staffing structure (e.g. in terms of workforce development), and sometimes by a completely different understanding of business. For this reason, change management must be integrated as part of the development of competencies in companies especially among managers. Small and medium enterprises, in particular, often need external support in implementing change management processes, although it should be borne in mind that it is often economically inexpedient for such companies to seek management consultants. In addition, further training should be anchored as an ongoing strategic objective in management and human resources departments.

Digitalization strategy development

The use of new and innovative technologies is an important aspect of Industry 4.0, although concepts for Industry 4.0 can also be implemented on a small scale. The large-scale use of modern technologies - from intelligent mobile devices for the employee through cloud services to offline, driverless transport systems - is usually inevitable. A key benefit (in keeping with the spirit of Industry 4.0) is that it allows the company to remain flexible and adaptive. Digitalization makes data more complete, fast and accurate, providing a transparent overview of the production system and all other areas of the business.

With strategic foresight, opportunities and risks to the company can be identified at an early stage and conclusions drawn to guide corporate strategy. Small and medium-sized enterprises in particular, despite their typically shortterm planning horizon, should regularly use this tool to raise awareness of Industry 4.0 and possible strategies for its implementation.

Professional development of employees

For the successful implementation of the Industry 4.0, employees must have the appropriate qualifications. This applies to all areas of qualification in enterprises: training in digitalization of content is just as important for dual training and qualified work as for all forms of further training. The most important qualification topics are data evaluation and analysis, process management and customer relationship management. This qualification must be continuous during the gradual implementation of Industry 4.0. 
INSIGHTS INTO REGIONAL DEVELOPMENT

ISSN 2669-0195 (online) http://jssidoi.org/jesi/

2021 Volume 3 Number 1 (March)

http://doi.org/10.9770/IRD.2021.3.1(7)

Make your research more visible, join the Twitter account of INSIGHTS INTO REGIONAL DEVELOPMENT:

@IntoInsights

For this purpose, it is important to make the qualification a management task. It is recommended that digital formats be used for content delivery. They can demonstrate correlations using real, digitally available process data. Smart terminals connected to the cyber level can provide employees with knowledge.

The development of holistic competence for Industry 4.0 requires the interaction of several actors, which takes place at different stages that can usually be divided into implementation, development, consolidation and sustainable linking. The management level plays an important role in this process. Other actors are universities and public educational institutions, private educational institutions, SME competence centres, non-governmental organizations, associations and trade unions. Their respective tasks are outlined in a road map for possible implementation (see table 2), which is one of the main results of the study. In order for the actors to find their role, an integrated information system is needed.

Further research may, in particular, contribute to the successful implementation of digital proposals in practice.

Table 2. Implementation roadmap for competence development in Industry 4.0

\begin{tabular}{|c|c|c|c|c|c|c|}
\hline Indicators & $\begin{array}{c}\text { Corporate } \\
\text { management }\end{array}$ & $\begin{array}{c}\text { Universities/public } \\
\text { education } \\
\text { institutions }\end{array}$ & $\begin{array}{c}\text { External } \\
\text { private } \\
\text { educational } \\
\text { institutions }\end{array}$ & $\begin{array}{c}\text { Centres of } \\
\text { competence } \\
\text { Industry } 4.0 \text { in } \\
\text { enterprises }\end{array}$ & $\begin{array}{c}\text { State } \\
\text { assistance }\end{array}$ & $\begin{array}{l}\text { Associations, } \\
\text { Chambers and } \\
\text { Unions }\end{array}$ \\
\hline $\begin{array}{c}\text { Requirements . } \\
\text { Creating the } \\
\text { foundation and } \\
\text { framework } \\
\text { conditions for } \\
\text { successful } \\
\text { implementation } \\
\text { of the Sector } \\
4.0\end{array}$ & $\begin{array}{l}\text { Use of new and } \\
\text { innovative } \\
\text { technologies } \\
\text { Digitization } \\
\text { strategy } \\
\text { development } \\
\text { Increased } \\
\text { awareness of new } \\
\text { business models, } \\
\text { platform } \\
\text { economy, digital } \\
\text { markets and data } \\
\text { sets }\end{array}$ & $\begin{array}{l}\text { Strengthening the } \\
\text { dual system } \\
\text { Strengthening } \\
\text { initial and } \\
\text { continuing teacher } \\
\text { training } \\
\text { Integration of all } \\
\text { stakeholders } \\
\text { Strengthening } \\
\text { scientific support } \\
\text { Media integration } \\
\text { and digitization of } \\
\text { content } \\
\text { Adapting academic } \\
\text { training }\end{array}$ & $\begin{array}{c}\text { Extension of } \\
\text { training and } \\
\text { professional } \\
\text { development of } \\
\text { teaching staff } \\
\text { Operational- } \\
\text { level } \\
\text { orientation } \\
\text { Media and } \\
\text { digital content } \\
\text { integration }\end{array}$ & $\begin{array}{c}\text { Institutionalization } \\
\text { of strategic } \\
\text { foresight } \\
\text { Creating } \\
\text { awareness of new } \\
\text { business models, } \\
\text { platform } \\
\text { economy, digital } \\
\text { markets and large } \\
\text { data sets }\end{array}$ & $\begin{array}{c}\text { Creation of } \\
\text { additional } \\
\text { education } \\
\text { system } \\
\text { Strengthening } \\
\text { the dual system } \\
\text { Strengthening } \\
\text { initial and } \\
\text { continuing } \\
\text { training of } \\
\text { teaching staff } \\
\text { Integration of } \\
\text { all stakeholders } \\
\text { Strengthening } \\
\text { scientific } \\
\text { support }\end{array}$ & $\begin{array}{c}\text { Integration of all } \\
\text { stakeholders } \\
\text { Creating } \\
\text { framework } \\
\text { conditions and } \\
\text { raising } \\
\text { awareness }\end{array}$ \\
\hline $\begin{array}{l}\text { Introduction } \\
\text { Make sense } \\
\text { and draw } \\
\text { attention to the } \\
\text { scale and } \\
\text { business } \\
\text { relevance of the } \\
\text { Industry } 4.0\end{array}$ & $\begin{array}{c}\text { Acquisition of } \\
\text { information and } \\
\text { composition of the } \\
\text { project team } \\
\text { Operational-level } \\
\text { orientation } \\
\text { Integration of all } \\
\text { stakeholders } \\
\text { Institutionalization } \\
\text { of the strategic } \\
\text { foresight approach } \\
\text { Targeted change } \\
\text { management }\end{array}$ & $\begin{array}{c}\text { Survey of } \\
\text { Educational } \\
\text { Achievement and } \\
\text { Competence } \\
\text { Implementation of } \\
\text { innovative } \\
\text { teaching-learning } \\
\text { solutions }\end{array}$ & $\begin{array}{l}\text { Education and } \\
\text { Competence } \\
\text { Survey } \\
\text { Initiation of a } \\
\text { neutral internet } \\
\text { platform for } \\
\text { educational } \\
\text { offers in } \\
\text { Industry } 4.0 \\
\text { Mediation of } \\
\text { digital } \\
\text { transformation } \\
\text { requirements } \\
\text { Implementation }\end{array}$ & $\begin{array}{c}\text { Creating } \\
\text { framework } \\
\text { conditions and } \\
\text { raising awareness } \\
\text { of competence } \\
\text { development for } \\
\text { the Industry } 4.0 \\
\text { Exchanges } \\
\text { between } \\
\text { enterprises } 4.0 \\
\text { Raising awareness } \\
\text { by informing } \\
\text { about the content } \\
\text { and benefits of the }\end{array}$ & $\begin{array}{l}\text { Information } \\
\text { campaign } \\
\text { Initiation of a } \\
\text { neutral } \\
\text { brokerage } \\
\text { platform for } \\
\text { educational } \\
\text { offers in the } \\
\text { industry } 4.0 \\
\text { Incentives } \\
\text { through } \\
\text { programs and } \\
\text { support } \\
\text { activities (e.g. }\end{array}$ & $\begin{array}{l}\text { Information } \\
\text { campaign } \\
\text { Networking and } \\
\text { assistance in } \\
\text { obtaining } \\
\text { information } \\
\text { Creation of } \\
\text { seminars and } \\
\text { special event } \\
\text { formats for } \\
\text { enterprise } \\
\text { managers }\end{array}$ \\
\hline
\end{tabular}


INSIGHTS INTO REGIONAL DEVELOPMENT

ISSN 2669-0195 (online) http://jssidoi.org/jesi/

2021 Volume 3 Number 1 (March)

http://doi.org/10.9770/IRD.2021.3.1(7)

Make your research more visible, join the Twitter account of INSIGHTS INTO REGIONAL DEVELOPMENT:

@ IntoInsights

\begin{tabular}{|c|c|c|c|c|c|c|}
\hline Indicators & $\begin{array}{c}\text { Corporate } \\
\text { management }\end{array}$ & $\begin{array}{c}\text { Universities/public } \\
\text { education } \\
\text { institutions }\end{array}$ & $\begin{array}{c}\text { External } \\
\text { private } \\
\text { educational } \\
\text { institutions }\end{array}$ & $\begin{array}{c}\text { Centres of } \\
\text { competence } \\
\text { Industry } 4.0 \text { in } \\
\text { enterprises }\end{array}$ & $\begin{array}{c}\text { State } \\
\text { assistance }\end{array}$ & $\begin{array}{c}\text { Associations, } \\
\text { Chambers and } \\
\text { Unions }\end{array}$ \\
\hline & & & $\begin{array}{l}\text { of innovative } \\
\text { teaching- } \\
\text { learning } \\
\text { solutions }\end{array}$ & $\begin{array}{c}\text { Industry } 4.0 \\
\text { Establishment of } \\
\text { demonstration } \\
\text { centres, seminars } \\
\text { and special } \\
\text { formats of events } \\
\text { for business } \\
\text { leaders }\end{array}$ & $\begin{array}{c}\text { digital } \\
\text { implementation } \\
\text { or individual } \\
\text { transfer } \\
\text { projects) } \\
\text { Creation of } \\
\text { flexible } \\
\text { framework } \\
\text { conditions for } \\
\text { the industry } 4.0\end{array}$ & \\
\hline $\begin{array}{l}\text { Development } \\
\text { Initialize the } \\
\text { theme across } \\
\text { the company } \\
\text { and create a } \\
\text { common } \\
\text { understanding } \\
\text { of the task }\end{array}$ & $\begin{array}{l}\text { Start event with a } \\
\text { message of } \\
\text { entrepreneurial } \\
\text { vision } \\
\text { New business } \\
\text { model } \\
\text { development }\end{array}$ & $\begin{array}{l}\text { Measures to train } \\
\text { trainers on the } \\
\text { content and } \\
\text { requirements of the } \\
\text { Industry } 4.0\end{array}$ & $\begin{array}{c}\text { Raising } \\
\text { awareness and } \\
\text { adapting } \\
\text { managers } \\
\text { through basic } \\
\text { workshops } \\
\text { Message about } \\
\text { digital } \\
\text { transformation } \\
\text { requirements }\end{array}$ & $\begin{array}{c}\text { Exchanges } \\
\text { between } \\
\text { companies } \\
\text { Funded consulting } \\
\text { workshops to } \\
\text { address industry } \\
\text { issues }\end{array}$ & $\begin{array}{c}\text { Incentives } \\
\text { through } \\
\text { programmes } \\
\text { and support } \\
\text { measures (e.g. } \\
\text { advisory } \\
\text { measures or } \\
\text { awareness } \\
\text { campaigns) } \\
\text { Support for } \\
\text { pilot projects } \\
\text { and openness } \\
\text { to pilot } \\
\text { approaches }\end{array}$ & $\begin{array}{l}\text { Actively } \\
\text { contribute to the } \\
\text { development and } \\
\text { conceptualization } \\
\text { of the integration } \\
\text { of people into the } \\
\text { Industry } 4.0\end{array}$ \\
\hline $\begin{array}{l}\text { Consolidation } \\
\text { Intensive } \\
\text { training of } \\
\text { specialists and } \\
\text { freedom of } \\
\text { decision } \\
\text { making for } \\
\text { project } \\
\text { managers }\end{array}$ & $\begin{array}{l}\text { Message about } \\
\text { digital conversion } \\
\text { requirements } \\
\text { Staff development }\end{array}$ & $\begin{array}{l}\text { Seminars and staff } \\
\text { training } \\
\text { Message about } \\
\text { digital conversion } \\
\text { requirements }\end{array}$ & $\begin{array}{l}\text { Providing } \\
\text { special training } \\
\text { programs for } \\
\text { individual } \\
\text { companies } \\
\text { Message about } \\
\text { digital } \\
\text { transformation } \\
\text { requirements }\end{array}$ & $\begin{array}{c}\text { Inter-business } \\
\text { exchange } \\
\text { Funded consulting } \\
\text { workshops to } \\
\text { address industry } \\
\text { issues }\end{array}$ & $\begin{array}{c}\text { Incentives } \\
\text { through } \\
\text { programmes } \\
\text { and support } \\
\text { measures (e.g. } \\
\text { for targeted } \\
\text { professional } \\
\text { development } \\
\text { and learning } \\
\text { measures). }\end{array}$ & $\begin{array}{c}\text { Creating } \\
\text { opportunities to } \\
\text { present best } \\
\text { practices through } \\
\text { networks and } \\
\text { sharing } \\
\text { experiences }\end{array}$ \\
\hline $\begin{array}{l}\text { Sustainability } \\
\text { Inform about } \\
\text { the current } \\
\text { status of the } \\
\text { project and } \\
\text { explain new } \\
\text { technological } \\
\text { developments }\end{array}$ & $\begin{array}{l}\text { Organization of } \\
\text { events within the } \\
\text { company } \\
\text { Ensuring the } \\
\text { transfer of } \\
\text { knowledge and } \\
\text { skills throughout } \\
\text { life } \\
\text { Staff development }\end{array}$ & $\begin{array}{c}\text { Ensuring the } \\
\text { transfer of } \\
\text { knowledge and } \\
\text { skills throughout } \\
\text { life } \\
\text { Adapting academic } \\
\text { training }\end{array}$ & $\begin{array}{l}\text { Ensuring the } \\
\text { transfer of } \\
\text { knowledge and } \\
\text { competence } \\
\text { throughout life }\end{array}$ & $\begin{array}{c}\text { Regular } \\
\text { information on } \\
\text { current } \\
\text { innovations and } \\
\text { technological } \\
\text { opportunities }\end{array}$ & $\begin{array}{l}\text { Strengthening } \\
\text { framework } \\
\text { conditions for } \\
\text { lifelong } \\
\text { learning }\end{array}$ & $\begin{array}{c}\text { Creating } \\
\text { opportunities to } \\
\text { present best } \\
\text { practices through } \\
\text { networks and } \\
\text { sharing } \\
\text { experiences }\end{array}$ \\
\hline
\end{tabular}

Source: composed by the authors 
INSIGHTS INTO REGIONAL DEVELOPMENT

ISSN 2669-0195 (online) http://jssidoi.org/jesi/

2021 Volume 3 Number 1 (March)

http://doi.org/10.9770/IRD.2021.3.1(7)

Make your research more visible, join the Twitter account of INSIGHTS INTO REGIONAL DEVELOPMENT:

@IntoInsights

\section{Conclusion}

The areas of data evaluation and analysis, process management and increasing process know-how, as well as interdisciplinary thinking and action, are regarded by enterprises as central elements of staff qualification for Industry 4.0. Information technology competences - above all as extensive knowledge - are also regarded as being of great importance for the fourth industrial revolution. When setting priorities for the future, differences will become apparent: while large companies pay particular attention to technology and data-oriented topics, small and medium-sized enterprises pay particular attention to customer-oriented processes as well as areas of competence related to infrastructure and organization.

The content of Industry 4.0 and digitalization should be integrated into company training and further education, existing offers should be systematically linked to each other and existing programmes should be purposefully developed. In this context, it is essential to strengthen all necessary competences and skills: those that are relevant for the implementation of Industry 4.0 at the production and technological level or in the design of customer relationships, as well as those in management and workforce that are relevant for the development of new business models and for understanding the economics of the Internet and platforms. In addition to traditional competency development tools, participatory learning platforms should also use digital educational offerings as well as learning cases, simulations or learning games (keyword: gamification).

In general, Kazakh companies have significant development potential for further implementation of digital technologies. This is especially true for small and medium-sized enterprises. Both in terms of implementation and intention to develop companies in digital format.

Against this background, it is obvious that it is necessary to raise awareness of digital changes in small and medium-sized businesses and to convey to them not only the benefits of Industry 4.0, but also clear strategies for its implementation. Specific (successful) implementation examples provide important impulses for the introduction of Industry 4.0 to SMEs, on the one hand (to be able to assess digitization opportunities for their business) and, on the other hand, to reduce concerns about high investment costs and uncertainty about depreciation of investments.

In order to facilitate and successfully develop competencies for the Industry, the study has developed the following recommendations for enterprises to act on:

1. Develop and implement strategies for Industry 4.0: Company decision makers must develop an understanding of the disruptive changes caused by Industry 4.0. It is important that companies derive from this understanding the strategies and measures for developing employee competencies and introducing new products, efficient processes, and innovative business models. The leadership competence of management is particularly relevant here (see in particular the implementation roadmap in Table 2).

2. Strengthen qualification and change management: Initial and continuing vocational training in enterprises should be adapted to Industry 4.0 and qualifications should be a priority. New digital methods offer effective entry points for this. In addition, it is important to adapt the work organisation and process as well as the framework conditions. Change management must be taken into account from the outset. 
INSIGHTS INTO REGIONAL DEVELOPMENT

ISSN 2669-0195 (online) http://jssidoi.org/jesi/

2021 Volume 3 Number 1 (March)

http://doi.org/10.9770/IRD.2021.3.1(7)

Make your research more visible, join the Twitter account of INSIGHTS INTO REGIONAL DEVELOPMENT:

@ IntoInsights

\section{References}

Abele E., Chryssolouris G., Sihn, Metternich W., et al. (2017). Learning factories for future oriented research and education in manufacturing, CIRP annals 66, 803-826.

Abele E., Metternich J., Tisch M., Chryssolouris G., Sihn W., ElMaraghy H., Hummel V., Ranz F. (2015). Learning factories for research, education, and training, Procedia CIRP.

Arnold, C., D., Kiel, D. Voigt. K. (2016). How the Industrial Internet of Things Changes Business Models in Different Manufacturing Industries. International Journal of Innovation Management, 20(8), 1-25.

Bauernhansl T., Krüger, G. Reinhart J., Schuh G. (2016). WGP-Standpunkt Industrie 4.0, Wissenschaftliche Gesellschaft für Produktionstechnik.

Boon-itt, S., \& Wong, C. Y. (2016). Empirical investigation of alternate cumulative capability models: A multi-method approach. Production Planning \& Control, 27(4), 299-311. https://doi.org/10.1080/09537287.2015.1124299

Boronenko V., Lavrinenko, O. (2015). Territorial development of Iceland: case study of social and economic interactions within global context. Social sciences for regional development in 2015: Proceedings of the X International scientific. Conf. (16-17 October 2015). Daugavpils University Latvia.

Brynjolfsson E., Kahin B. (editors). (2000). Understanding the Digital Economy, The MIT Press, Cambridge, Massachusetts, and London, England, 408 p.

Drath, R., \& Horch, A. (2014). Industrie 4.0: Hit or hype? IEEE Industrial Electronics Magazine, 8(2), 56-58. https://doi.org/10.1109/MIE.2014.2312079

Dzwigol, H., Dzwigol-Barosz, M., Miskiewicz, R., Kwilinski, A. 2020. Manager competency assessment model in the conditions of industry 4.0. Entrepreneurship and Sustainability Issues, 7(4), 2630-2644. http://doi.org/10.9770/jesi.2020.7.4(5)

Enke, J., Kraft, K., Metternich, J. 2015. Competency-oriented Design of Learning Modules. Procedia CIRP 32, 7-12.

Frank, G., Santos Dalenogare, L., Ayala, N. F. (2019, April). Industry 4.0 technologies: Implementation patterns in manufacturing companies. International Journal of Production Economics, 210(4), 15-26. https://doi.org/10.1016/j.ijpe.2019.01.004

Ghadge, A., Er Kara, M., Moradlou, H., Goswami, M. (2020). The impact of Industry 4.0 implementation on supply chains. Journal of Manufacturing Technology Management, 31(4), 669-686. https://doi.org/10.1108/JMTM-10-2019-0368

Gubbi, J., Buyya, R., Marusic, S., \& Palaniswami, M. (2013, September). Internet of things (IoT): A vision, architectural elements, and future directions. Future Generation Computer Systems, 29(7), 1645-1660. https://doi.org/10.1016/j.future.2013.01.010

Kagermann, H., Wahlster, W., Helbig, J. 2013. Umsetzungsempfehlungen für das Zukunftsprojekt Industrie 4.0: Abschlussbericht des Arbeitskreises Industrie 4.0, Forschungsunion.

Kusiak, A. (2018). Smart manufacturing. International Journal of Production Research, 56(1-2), 508-517, Leading scholars in Production Research for the 55th volume anniversary of IJPR. https://doi.org/10.1080/00207543.2017.1351644

Lasi, H., F. Peter, F. Thomas, Hoffmann, M. (2014). "Industry 4.0.” Business \& Information Systems Engineering, 6(4), $239-242$. https://doi.org/10.1007/s12599-014-0334-4

Liker, J.K. 2004. The Toyota way: 14 management principles from the world's greatest manufacturer. McGraw-Hill, New York u.a.

Metternich, J., Adolph, S., Hambach, J., Hertle, C. et al. 2017. Lean 4.0: Durch Digitalisierung die nächste Stufe der Exzellenz erreichen der Darmstädter Ansatz, Praxishandbuch Industrie 4.0: Branchen - Unternehmen - M\&A. 
INSIGHTS INTO REGIONAL DEVELOPMENT

ISSN 2669-0195 (online) http://jssidoi.org/jesi/

2021 Volume 3 Number 1 (March)

http://doi.org/10.9770/IRD.2021.3.1(7)

Make your research more visible, join the Twitter account of INSIGHTS INTO REGIONAL DEVELOPMENT:

@IntoInsights

Meudt T., Metternich J., Abele E. 2017. Value stream mapping 4.0: Holistic examination of value stream and information logistics in production, CIRP Annals-Manufacturing Technology 66, 413-416.

Monostori, L., Kádár, B., Bauernhansl, T., Kondoh, S. et al. 2016. Cyber-physical systems in manufacturing, CIRP Annals-Manufacturing Technology 65, 621-641.

Oesterreich, T., Teuteberg, F. 2016. Understanding the Implications of Digitization and Automation in the Context of Industry 4.0: A Triangulation Approach and Elements of a Research Agenda for the Construction Industry. Computers in Industry, 83, 121-139. https://doi.org/10.1016/j.compind.2016.09.006

Peruzzini, M., F. Gregori, A. Luzi, M. Mengarelli, and M. Germani. 2017. A Social Life Cycle Assessment Methodology for Smart Manufacturing: The Case of Study of a Kitchen Sink. Journal of Industrial Information Integration, 7, $24-32$. https://doi.org/10.1016/j.jii.2017.04.001

Romero, D., Vernadat, F. (2016). Enterprise Information Systems State of the Art: Past, Present and Future Trends. Computers in Industry, 79, 3-13. https://doi.org/10.1016/j.compind.2016.03.001

Shevyakova, A., Shalaev, V., Vechkinzova, E., Vatyukova, O. (2019). Innovative economy in the 21st century: contradiction and opposition of developed and developing countries. In: The 21st Century from the Positions of Modern Science: Intellectual, Digital and Innovative Aspects. In: Popkova E. (eds). ISC 2019. Lecture Notes in Networks and Systems, vol 91. Springer, Cham, 552-560. https://doi.org/10.1007/978-3-030-32015-7_62

Shevyakova, A., Petrenko E. (2019). Features and Perspectives of Digitization in Kazakhstan// Ubiquitous Computing and the Internet of Things: Prerequisites for the Development of ICT. Studies in Computational Intelligence. In: Popkova E. (eds). 2019, vol 826. Springer, Cham. https://doi.org/10.1007/978-3-030-13397-9_91

Ślusarczyk, B., Tvaronavičienė, M., U1 Haque, A., \& Oláh, J. 2020. Predictors of Industry 4.0 technologies affecting logistic enterprises' performance: international perspective from economic lens. Technological and Economic Development of Economy, 26(6), 1263-1283. https://doi.org/10.3846/tede.2020.13376

Tisch, M., Cachay, J., Abele, E., Metternich, J. et al. (2013). A Systematic Approach on Developing Action-oriented, Competency-based Learning Factories, Procedia CIRP 7, 580-585.

Tvaronaviciene, M., Burinskas, A. (2020). Industry 4.0 significance to competition and the EU competition policy: A literature review. Economics and Sociology, 13(3), 244-258

World Economic Forum. 2016. The Future of Jobs. Employment, Skills and Workforce Strategy for the Fourth Industrial Revolution, http://www3.weforum.org/docs/WEF Future of Jobs.pdf

Wyrwa, J. 2020. A review of the European Union financial instruments supporting the innovative activity of enterprises in the context of Industry 4.0 in the years 2021-2027. Entrepreneurship and Sustainability Issues, 8(1), 1146-1161. http://doi.org/10.9770/jesi.2020.8.1(77)

Xu, E. L., \& Li, L. (2018). Industry 4.0: State of the art and future trends. International Journal of Production Research, 56(8), 2941-2962. https://doi.org/10.1080/00207543.2018.1444806 
INSIGHTS INTO REGIONAL DEVELOPMENT

ISSN 2669-0195 (online) http://jssidoi.org/jesi/

2021 Volume 3 Number 1 (March)

http://doi.org/10.9770/IRD.2021.3.1(7)

Make your research more visible, join the Twitter account of INSIGHTS INTO REGIONAL DEVELOPMENT:

@ IntoInsights

Acknowledgements

This research was supported by the project, which has received funding from Committee of Science of the Ministry of Education and Science of the Republic of Kazakhstan within the framework of scientific grant AP05134987 "Innovative receptivity of national economies of the EAEC countries: system characteristics, evaluation, management mechanisms".

\begin{abstract}
Anna SHEVYAKOVA, Doctor of Economics, Senior Researcher, LLP "Rational solutions". Her research interests are related to macroeconomics, economic diversification, regional specialization, budget financing and state support for entrepreneurship development, innovation and development of "smart" territories.
\end{abstract}

ORCID ID: orcid.org/0000-0002-2644-6292

Eleonora MUNSH, Master of Engineering and Technology, Training and Development Department, EPAM Kazakhstan. Her research interests are related to Kazakhstan's economic sectors, pre-employment, non-governmental organizations, information technologies and support, computer networks, psychology and sociology.

ORCID ID: orcid.org/0000-0003-2395-6403

Malika ARYSTAN, PhD, Associate Professor, Department of economic and management, Karaganda Economic University. Research interests are related to micro- and macroeconomics, international and regional economic development, state economic policy, factors of economic growth.

ORCID ID: orcid.org/0000-0003-4921-6577

Yelena PETRENKO, Doctor of economics, professor, Plekhanov Russian University of Economic. She is an expert of the European Bank for Reconstruction and Development in Kazakhstan. Her research interests are related to strategic management, human resources management, sustainability of companies, entrepreneurship, marketing.

ORCHID ID: orcid.org/0000-0001-6892-2392

Copyright (C) 2021 by author(s) and VsI Entrepreneurship and Sustainability Center

This work is licensed under the Creative Commons Attribution International License (CC BY).

http://creativecommons.org/licenses/by/4.0/

(c) (†) Open Access 